\title{
Chapter 4 Variability of Carbon Dioxide and Methane in the Epilimnion of Lake Kivu
}

\author{
Alberto V. Borges, Steven Bouillon, Gwenaël Abril, Bruno Delille, \\ Dominique Poirier, Marc-Vincent Commarieu, Gilles Lepoint, \\ Cédric Morana, Willy Champenois, Pierre Servais, Jean-Pierre Descy, \\ and François Darchambeau
}

\begin{abstract}
We report a dataset of the partial pressure of $\mathrm{CO}_{2}\left(\mathrm{pCO}_{2}\right)$ and methane concentrations $\left(\mathrm{CH}_{4}\right)$ in the surface waters of Lake Kivu obtained during four cruises covering the two main seasons (rainy and dry). Spatial gradients of surface $\mathrm{pCO}_{2}$ and $\mathrm{CH}_{4}$ concentrations were modest in the main basin. In Kabuno Bay, $\mathrm{pCO}_{2}$ and $\mathrm{CH}_{4}$ concentrations in surface waters were higher, owing to the stronger influence of subaquatic springs from depth. Seasonal variations of $\mathrm{pCO}_{2}$ and $\mathrm{CH}_{4}$ in the main basin of Lake Kivu were strongly driven by deepening of the epilimnion and the resulting entrainment of water characterized by higher $\mathrm{pCO}_{2}$ and $\mathrm{CH}_{4}$ concentrations. Physical and chemical vertical patterns in Kabuno Bay were seasonally stable, owing to a stronger stratification and smaller surface area inducing fetch limitation
\end{abstract}

\footnotetext{
A.V. Borges $(\bowtie) \bullet$ B. Delille $\bullet$ M.-V. Commarieu $\bullet$ W. Champenois $\bullet$ F. Darchambeau Chemical Oceanography Unit, University of Liège, Liège, Belgium e-mail: alberto.borges@ulg.ac.be; bruno.delille@ulg.ac.be; marc-vincent.commarieu@ulg.ac.be; willy.champenois@ulg.ac.be; francois.darchambeau@ulg.ac.be

S. Bouillon • C. Morana

Departement Aard- en Omgevingswetenschappen, Katholieke Universiteit Leuven, Leuven, Belgium e-mail: steven.bouillon@ees.kuleuven.be; cedric.morana@ees.kuleuven.be

G. Abril

Laboratoire Environnements et Paléoenvironnements Océaniques,

Université de Bordeaux 1, France

Institut de Recherche pour le Développement, Laboratorio de Potamologia Amazônica, Universidad Federal do Amazonas, Manaus, Brazil

e-mail: g.abril@epoc.u-bordeaux1.fr

D. Poirier

Laboratoire Environnements et Paléoenvironnements Océaniques,

Université de Bordeaux 1, France

e-mail: d.poirier@epoc.u-bordeaux1.fr
} 
of wind driven turbulence. A global and regional cross-system comparison of $\mathrm{pCO}_{2}$ and $\mathrm{CH}_{4}$ concentrations in surface waters of lakes highlights the peculiarity of Kabuno Bay in terms of $\mathrm{pCO}_{2}$ values in surface waters. In terms of surface $\mathrm{CH}_{4}$ concentrations, both Kabuno Bay and the main basin of Lake Kivu are at the lower end of values in lakes globally, despite the huge amounts of $\mathrm{CH}_{4}$ and $\mathrm{CO}_{2}$ in the deeper layers of the lake.

\subsection{Introduction}

Freshwater environments are important components of the global carbon (C) cycle, as they fix carbon dioxide $\left(\mathrm{CO}_{2}\right)$ into organic matter and transport organic and inorganic $\mathrm{C}$ from the terrestrial biosphere to the oceans. This transport of $\mathrm{C}$ is not passive and freshwater ecosystems transform, store and exchange $\mathrm{C}$ with the atmosphere (Cole et al. 2007; Battin et al. 2008; Marotta et al. 2009; Tranvik et al. 2009). Freshwater ecosystems are considered to be frequently net heterotrophic, whereby the consumption of organic $\mathrm{C}$ is higher than the autochthonous production of organic $\mathrm{C}$, and excess organic $\mathrm{C}$ consumption is maintained by inputs of allochthonous organic C (Cole and Caraco 2001). Net heterotrophy in freshwater ecosystems promotes the emission of $\mathrm{CO}_{2}$ to the atmosphere, with the global emission from continental waters estimated at $\sim 0.75 \mathrm{Pg} \mathrm{C}_{\text {year }}{ }^{-1}$ (Cole et al. 2007; $0.11 \mathrm{Pg} \mathrm{C}_{\text {year }}{ }^{-1}$ from lakes, $0.28 \mathrm{Pg} \mathrm{C}$ year ${ }^{-1}$ from reservoirs, $0.23 \mathrm{Pg} \mathrm{C}$ year ${ }^{-1}$ from rivers, $0.12 \mathrm{Pg} \mathrm{C}_{\text {year }}{ }^{-1}$ from estuaries, and $0.01 \mathrm{Pg} \mathrm{C}$ year $^{-1}$ from ground waters). Such an emission of $\mathrm{CO}_{2}$ from continental waters is comparable to the sink of $\mathrm{C}$ by terrestrial vegetation and soils of $\sim 1.3 \mathrm{Pg} \mathrm{C}_{\text {year-1 }}{ }^{-1}$ (Cole et al. 2007) and the sink of $\mathrm{CO}_{2}$ in open oceans of $\sim 1.4 \mathrm{Pg} \mathrm{C}_{\text {year }}{ }^{-1}$ (Takahashi et al. 2009). Part of the degradation of organic $\mathrm{C}$ that occurs in freshwater ecosystems is mediated by anaerobic processes, among which methanogenesis, which leads to the emission of methane $\left(\mathrm{CH}_{4}\right)$ to the atmosphere. The global emission of $\mathrm{CH}_{4}$ to the atmosphere from freshwater ecosystems has been recently re-evaluated by Bastviken et al. (2011) to $103 \mathrm{Tg} \mathrm{CH}_{4}$ year $^{-1}\left(72 \mathrm{Tg} \mathrm{CH}_{4}\right.$ year $^{-1}$ from lakes) which is significant when compared

\footnotetext{
G. Lepoint

Laboratoire d'Océanologie, Université de Liège, Liège, Belgium

e-mail: g.lepoint@ulg.ac.be

P. Servais

Ecologie des Systèmes Aquatiques, Université Libre de Bruxelles, Brussels, Belgium e-mail: pservais@ulb.ac.be

J.-P. Descy

Research Unit in Environmental and Evolutionary Biology,

University of Namur, Namur, Belgium

e-mail: jpdescy@fundp.ac.be
} 
to other natural $\left(168 \mathrm{Tg} \mathrm{CH}_{4}\right.$ year $\left.^{-1}\right)$ and anthropogenic $\left(428 \mathrm{Tg} \mathrm{CH}_{4}\right.$ year $\left.^{-1}\right) \mathrm{CH}_{4}$ emissions (Chen and Prinn 2006).

Our present understanding of the role of lakes on $\mathrm{C}$ emissions could be biased because most observations were obtained in temperate and boreal systems, and in general in medium to small sized lakes, while much less observations are available from large tropical lakes. Tropical freshwater environments are indeed undersampled compared to temperate and boreal systems in terms of $\mathrm{C}$ dynamics in general, and specifically in terms of $\mathrm{CO}_{2}$ and $\mathrm{CH}_{4}$ dynamics. Yet, about $50 \%$ of freshwater and an equivalent fraction of organic $\mathrm{C}$ is delivered by rivers to the oceans at these latitudes (Ludwig et al. 1996). Tropical lakes represent about 16\% of the total surface of lakes (Lehner and Döll 2004), and Lakes Victoria, Tanganyika and Malawi belong to the seven largest lakes by area in the world.

We report the seasonal and spatial variability of $\mathrm{CO}_{2}$ and $\mathrm{CH}_{4}$ in the epilimnion of Lake Kivu, the smallest of the East African Rift lakes $\left(2,370 \mathrm{~km}^{2}\right)$. It is a deep (maximum depth of $485 \mathrm{~m}$ ), meromictic and oligotrophic lake (Chap. 5), characterized by a relatively simple pelagic foodweb (Chap. 8), with physical processes (vertical mixing and transport processes) that are different from most other lakes in the world (Chap. 2). Subaquatic springs provide heat, dissolved salts and $\mathrm{CO}_{2}$ to the bottom waters of the lake (Chap. 2). A prominent feature of Lake Kivu is the huge amounts of $\mathrm{CO}_{2}$ and $\mathrm{CH}_{4}$ (300 and $60 \mathrm{~km}^{3}$, respectively, at $0^{\circ} \mathrm{C}$ and $1 \mathrm{~atm}$, Schmid et al. 2005) that are dissolved in its deep waters. While $\mathrm{CO}_{2}$ is mainly of magmatic origin, $\mathrm{CH}_{4}$ originates for two thirds from anoxic bacterial reduction of $\mathrm{CO}_{2}$ and for one third from anaerobic degradation of settling organic material (Schoell et al. 1988).

Seasonality of the physical and chemical vertical structure (Chap. 2) and biological activity (Chaps. 5, 6,7) in surface waters of Lake Kivu is driven by the oscillation between the dry season (June-September) and the rainy season (October-May), the former characterized by dryer winds and a deepening of the surface mixed layer.

\subsection{Material and Methods}

In order to capture the seasonal variation of the studied quantities, four cruises were carried out in Lake Kivu on 15/03-29/03/2007 (mid rainy season), 28/08-10/09/2007 (late dry season), 21/06-03/07/2008 (early dry season) and 21/04-05/05/2009 (late rainy season). Sampling was carried out at 15 stations distributed over the whole lake (Fig. 4.1).

Vertical profiles of temperature, conductivity, oxygen and $\mathrm{pH}$ were obtained with a Yellow Springs Instrument (YSI) 6600 V2 probe. Calibration of sensors was carried out prior to the cruises and regularly checked during the cruises. The conductivity cell was calibrated with a $1,000 \mu \mathrm{S} \mathrm{cm}^{-1}\left(25^{\circ} \mathrm{C}\right)$ YSI standard. The $\mathrm{pH}$ electrode was calibrated with $\mathrm{pH} 4.00\left(25^{\circ} \mathrm{C}\right)$ and $\mathrm{pH} 7.00\left(25^{\circ} \mathrm{C}\right)$ National Institute of Standards and Technology (YSI) buffers. The oxygen membrane probe was calibrated with humidity saturated ambient air. Salinity was computed from specific conductivity according to Chap. 2. 


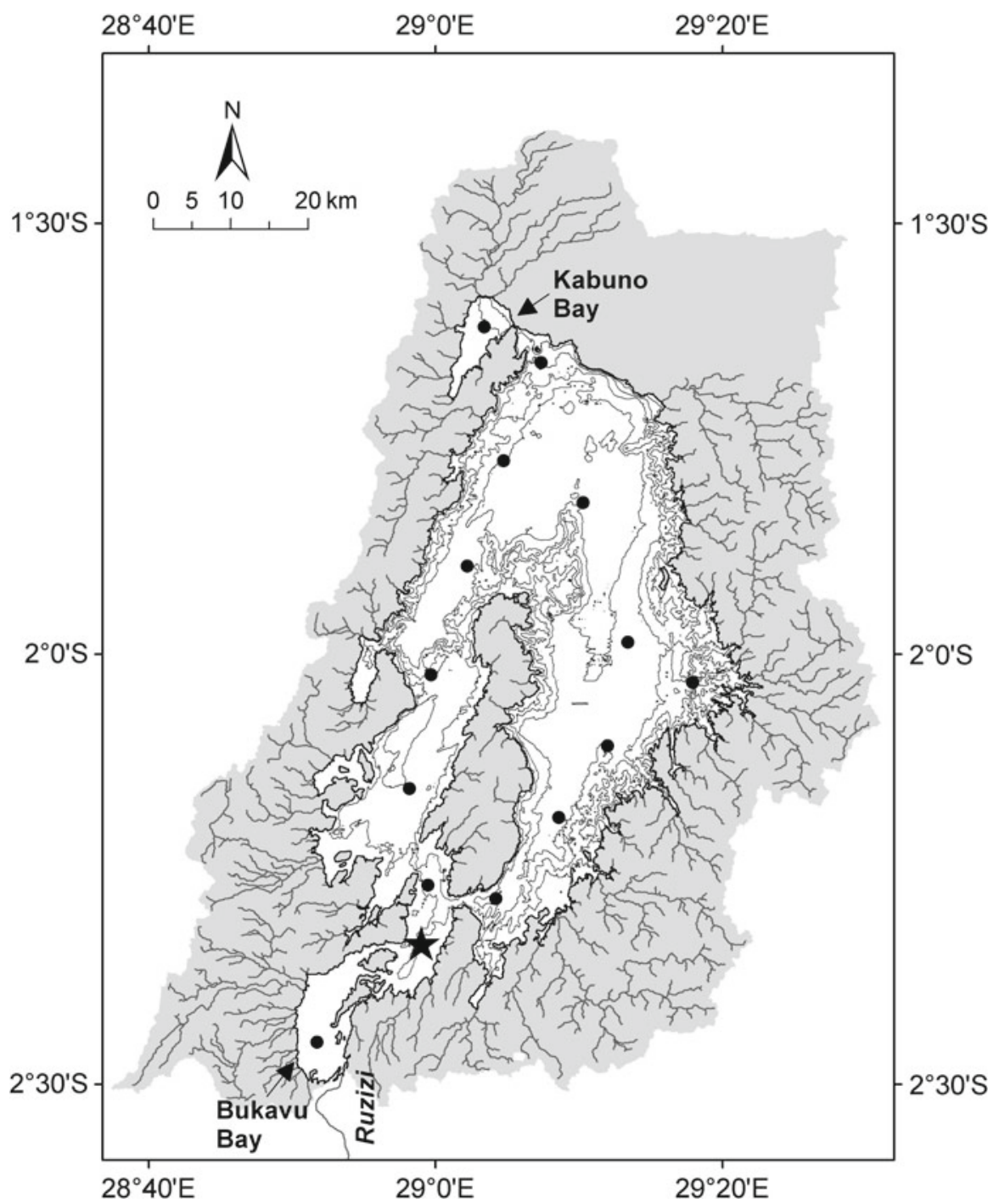

Fig. 4.1 Map of Lake Kivu, showing bathymetry (isobaths at $100 \mathrm{~m}$ intervals), catchment area (shaded in grey), tributaries (courtesy of Martin Schmid), and sampling stations. The station identified with a star corresponds to the site of $24 \mathrm{~h}$ measurement cycle carried out in March 2007

Sampling for the partial pressure of $\mathrm{CO}_{2}\left(\mathrm{pCO}_{2}\right)$ was carried out at $10 \mathrm{~m}$, with the exception of a $24 \mathrm{~h}$ cycle in March 2007 for which data at 1 and $5 \mathrm{~m}$ are also presented. Measurements of $\mathrm{pCO}_{2}$ were carried out with a non-dispersive infrared (NDIR) analyzer coupled to an equilibrator (Frankignoulle et al. 2001) through which water was pumped with a peristaltic pump (Masterflex E/S portable 
sampler). The sampling depth was determined with a DIMED S.A. Electronic Engineering PDCR 1730 pressure transducer. In situ temperature and temperature at the outlet of the equilibrator were determined with Li-Cor 1000-15 probes. The NDIR analyzer (Li-Cor, Li-820) was calibrated with pure nitrogen, and four gas standards with a $\mathrm{CO}_{2}$ molar fraction of $363,819,3,997$ and 8,170 ppm (Air Liquide Belgium).

Water for the determination of $\mathrm{pH}, \mathrm{CH}_{4}$ concentrations, $\delta^{13} \mathrm{C}$ of dissolved inorganic carbon (DIC), total alkalinity (TA) and total organic carbon (TOC) concentrations was sampled with a $5 \mathrm{~L}$ Niskin bottle (Hydro-Bios). Samples were collected every $10 \mathrm{~m}$ from 10 to $60-80 \mathrm{~m}$ depending on the cruise and station, except for $\mathrm{CH}_{4}$ which was only sampled at $10 \mathrm{~m}$. Additional samples for $\mathrm{pH}, \delta^{13} \mathrm{C}_{\mathrm{DIC}}$ and TA were collected at $5 \mathrm{~m}$ in Kabuno Bay. Water for $\mathrm{CH}_{4}$ analysis was collected in glass serum bottles from the Niskin bottle with tubing, left to overflow, poisoned with $100 \mu \mathrm{L}$ of saturated $\mathrm{HgCl}_{2}$ and sealed with butyl stoppers and aluminium caps. Water samples for the analysis of $\delta^{13} \mathrm{C}_{\mathrm{DIC}}$ were taken from the same Niskin bottle by gently overfilling $12 \mathrm{~mL}$ glass headspace vials, poisoning with $20 \mu \mathrm{L}$ of a saturated $\mathrm{HgCl}_{2}$ solution, and gas-tight capped. A water volume of $50 \mathrm{~mL}$ was filtered through a $0.2 \mu \mathrm{m}$ pore size polysulfone filter and was stored at ambient temperature in polyethylene bottles for the determination of TA. Unfiltered water samples $(20 \mathrm{~mL})$ were preserved with $\mathrm{NaN}_{3}(0.05 \%$ final concentration) for the determination of TOC.

Measurements of $\mathrm{pH}$ in water sampled from the Niskin bottle were carried out with a Metrohm (6.0253.100) combined electrode calibrated with US National Bureau of Standards buffers of $\mathrm{pH} 4.002\left(25^{\circ} \mathrm{C}\right)$ and $\mathrm{pH} 6.881\left(25^{\circ} \mathrm{C}\right)$ prepared according to Frankignoulle and Borges (2001). Measurements of TA were carried out by open-cell titration with $\mathrm{HCl} 0.1 \mathrm{M}$ according to Gran (1952) on $50 \mathrm{~mL}$ water samples, and data were quality checked with Certified Reference Material acquired from Andrew Dickson (Scripps Institution of Oceanography, University of California, San Diego). DIC was computed from $\mathrm{pH}$ and TA measurements using the carbonic acid dissociation constants of Millero et al. (2006). For the analysis of $\delta^{13} \mathrm{C}_{\mathrm{DIC}}$, a He headspace was created in $12 \mathrm{~mL}$ glass vials, and $\sim 300 \mu \mathrm{L}$ of $\mathrm{H}_{3} \mathrm{PO}_{4}$ was added to convert all inorganic carbon species to $\mathrm{CO}_{2}$. After overnight equilibration, part of the headspace was injected into the He stream of an elemental analyser isotope ratio mass spectrometer (ThermoFinnigan Flash1112 and ThermoFinnigan Delta + XL, or Thermo FlashEA/HT coupled to Thermo Delta V) for $\delta^{13} \mathrm{C}$ measurements. The obtained $\delta^{13} \mathrm{C}$ data were corrected for the isotopic equilibration between gaseous and dissolved $\mathrm{CO}_{2}$ using an algorithm similar to that presented by Miyajima et al. (1995), and calibrated with LSVEC and NBS-19 certified standards or internal standards calibrated with the former. TOC was determined using a Dohrman Apollo 2000 TOC analyzer. As in surface waters of Lake Kivu particulate organic carbon contributes to $\sim 20 \%$ of TOC (not shown), we refer to dissolved organic carbon (DOC) for the purpose of the cross-lake $\mathrm{pCO}_{2}$ comparison (hereafter). Concentrations of $\mathrm{CH}_{4}$ were determined by gas chromatography $(\mathrm{GC})$ with flame ionization detection (GC-FID, Hewlett Packard HP 5890A), after creating a $12 \mathrm{~mL}$ headspace with $\mathrm{N}_{2}$ in $40 \mathrm{~mL}$ glass serum bottles, as described by Abril and Iversen (2002). After creating the $\mathrm{N}_{2}$ headspace, samples were vigorously shaken during $1 \mathrm{~min}$, were 
placed in a thermostated bath overnight $(\sim 16 \mathrm{~h})$ after which samples were again vigorously shaken during 1 min before starting the $\mathrm{GC}$ analysis. Certified $\mathrm{CH}_{4}: \mathrm{N}_{2}$

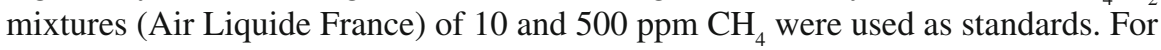
the March 2009 cruise, $\mathrm{CH}_{4}$ measurements were carried out with the same procedures but using $30 \mathrm{~mL}$ headspace with $\mathrm{N}_{2}$ in $70 \mathrm{~mL}$ serum bottles, and a SRI 8610C GC-FID calibrated with $\mathrm{CH}_{4}: \mathrm{CO}_{2}: \mathrm{N}_{2}$ mixtures (Air Liquide Belgium) of 1 and $10 \mathrm{ppm} \mathrm{CH}_{4}$. The concentrations were computed using the $\mathrm{CH}_{4}$ solubility coefficient given by Yamamoto et al. (1976).

Diffusive air-water $\mathrm{CO}_{2}$ and $\mathrm{CH}_{4}$ fluxes $(\mathrm{F})$ were computed according to:

$$
F=k \Delta[C]
$$

where $k$ is the gas transfer velocity and $\Delta[\mathrm{C}]$ is the air-water gradient of $\mathrm{CO}_{2}$ or $\mathrm{CH}_{4}$, using an atmospheric $\mathrm{pCO}_{2}$ value ranging from $\sim 372$ to $\sim 376 \mathrm{ppm}$ (depending on the cruise) and an atmospheric $\mathrm{CH}_{4}$ partial pressure of $1.8 \mathrm{ppm}$.

$k$ was computed from wind speed using the parameterization of Cole and Caraco (1998) and the Schmidt number of $\mathrm{CO}_{2}$ or $\mathrm{CH}_{4}$ in fresh water according to the algorithms given by Wanninkhof (1992). Wind speed data were acquired with a Davis Instruments meteorological station in Bukavu $\left(2.51^{\circ} \mathrm{S} 28.86^{\circ} \mathrm{E}\right)$. F was computed with daily wind speed averages for a time period of one month centred on the date of the middle of each field cruise. Such an approach allows to account for the dayto-day variability of wind speed, and to provide $\mathrm{F}$ values that are seasonally representative.

\subsection{Results and Discussion}

\subsubsection{Spatial Variability of $\mathrm{PCO}_{2}$ and $\mathrm{CH}_{4}$}

In the surface waters (10 $\mathrm{m}$ depth) of the main basin of Lake Kivu (excluding Kabuno Bay but including Bukavu Bay), $\mathrm{pCO}_{2}$ values were systematically above atmospheric equilibrium ( $\sim 372$ to $\sim 376$ ppm depending on the cruise), and varied within narrow ranges of 537-603 ppm in March 2007, 702-775 ppm in September 2007, 597-640 ppm in June 2008, and 581-711 ppm in April 2009 (Fig. 4.2). The coefficient of variation of $\mathrm{pCO}_{2}$ in surface waters of the main basin ranged for each cruise between $3 \%$ and $6 \%$, below the range reported by Kelly et al. (2001) in five large boreal lakes (range 5-40\%).

The most prominent feature of the spatial variation was the much higher $\mathrm{pCO}_{2}$ values in Kabuno Bay ranging between 13,158 and 14,793 ppm (between 18 and 26 times higher than in the main basin). Compared to the main basin, surface and deep waters of Kabuno Bay were characterized by higher salinity, DIC and TA values (Figs. 4.3 and 4.4) and by lower $\mathrm{pH}$ and $\delta^{13} \mathrm{C}_{\mathrm{DIC}}$ values (Figs. 4.3 and 4.4). Comparison of DIC and TA profiles (Fig. 4.4) shows that the relative contribution of $\mathrm{CO}_{2}$ to DIC is more important in Kabuno Bay than in the main lake, since TA is 

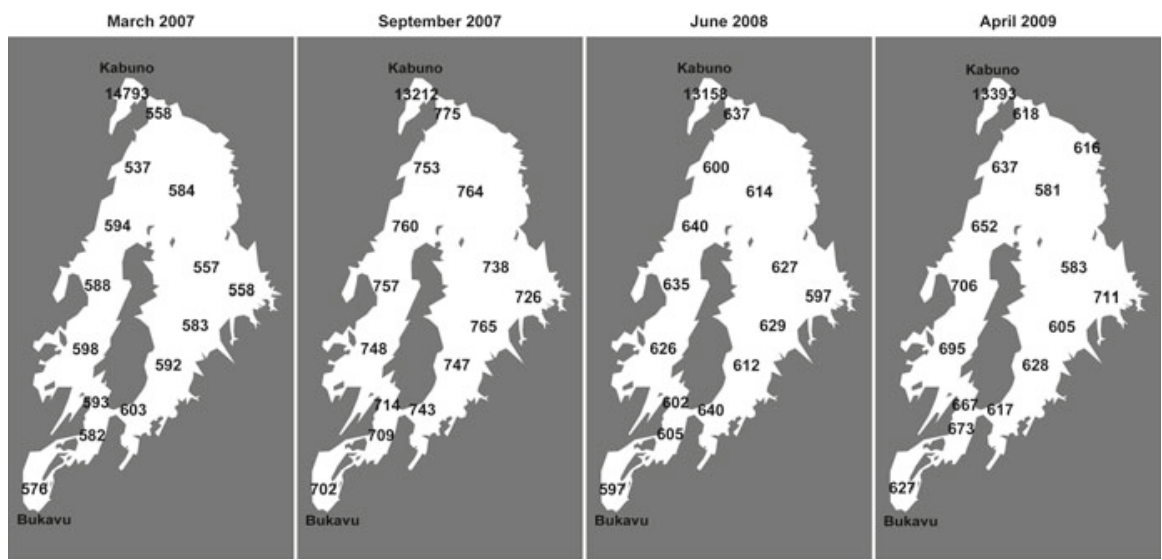

Fig. 4.2 Spatial distribution of the partial pressure of $\mathrm{CO}_{2}\left(\mathrm{pCO}_{2}, \mathrm{ppm}\right)$ in the surface waters of Lake Kivu (10 m depth) in March 2007, September 2007, June 2008 and April 2009

mainly as $\mathrm{HCO}_{3}^{-}$, and if the $\mathrm{CO}_{2}$ contribution to DIC is low, then DIC and TA should be numerically close. At $60 \mathrm{~m}$ depth, $\mathrm{CO}_{2}$ contributes $\sim 30 \%$ to DIC in Kabuno Bay, and $\sim 1 \%$ in the main basin. Kabuno Bay was also characterized by a very stable chemocline (salinity, $\mathrm{pH}$ ) and oxycline at $\sim 11 \mathrm{~m}$ irrespective of the sampling period (Fig. 4.3). In the main basin of Lake Kivu, the oxycline varied seasonally between $35 \mathrm{~m}$ in March and September 2007 and $~ 60 \mathrm{~m}$ in June 2008 (Fig. 4.3). Overall, these vertical patterns indicate that there is a much larger contribution of subaquatic springs to the whole water column including surface waters in Kabuno Bay than in the main basin of Lake Kivu. This is related to the different geomorphology, since Kabuno Bay is shallower than the main basin (maximum depth of $110 \mathrm{~m}$ vs. $485 \mathrm{~m}$ ) and exchanges little water with the main basin (narrow connection $\sim 10 \mathrm{~m}$ deep). Also, Kabuno Bay is smaller $\left(\sim 48 \mathrm{~km}^{2}\right)$ than the main basin $\left(\sim 2,322 \mathrm{~km}^{2}\right)$. Hence, there is a stronger fetch limitation of wind induced turbulence that also contributes to the stability of the water column vertical structure in Kabuno Bay whatever the season.

Part of the observed horizontal gradients of $\mathrm{pCO}_{2}$ in the main basin of Lake Kivu could be related to diel variations, since measurements were carried out irrespective of the time of the day (mostly from dawn to dusk, but sometimes at night). We investigated the diel cycle of $\mathrm{pCO}_{2}$ during a $24 \mathrm{~h}$ cycle on 23/03-24/03/2007 (Fig. 4.5). The amplitudes of the daily variations of $\mathrm{pCO}_{2}$ at the three depths were similar ( 30 ppm), but $\mathrm{pCO}_{2}$ during day-time was up to $\sim 30 \mathrm{ppm}$ higher at $1 \mathrm{~m}$ than at $5 \mathrm{~m}$ and $10 \mathrm{~m}$ depth. This was related to shallow stratification during day-time, with temperatures at $1 \mathrm{~m}$ depth up to $1.05^{\circ} \mathrm{C}$ and $1.15^{\circ} \mathrm{C}$ higher than at 5 and $10 \mathrm{~m}$ depth, respectively. At the end of the night the top $10 \mathrm{~m}$ water column became isothermal, due to heat loss to the atmosphere and convection of surface waters. In order to remove the effect of temperature change on the $\mathrm{CO}_{2}$ solubility coefficient, 

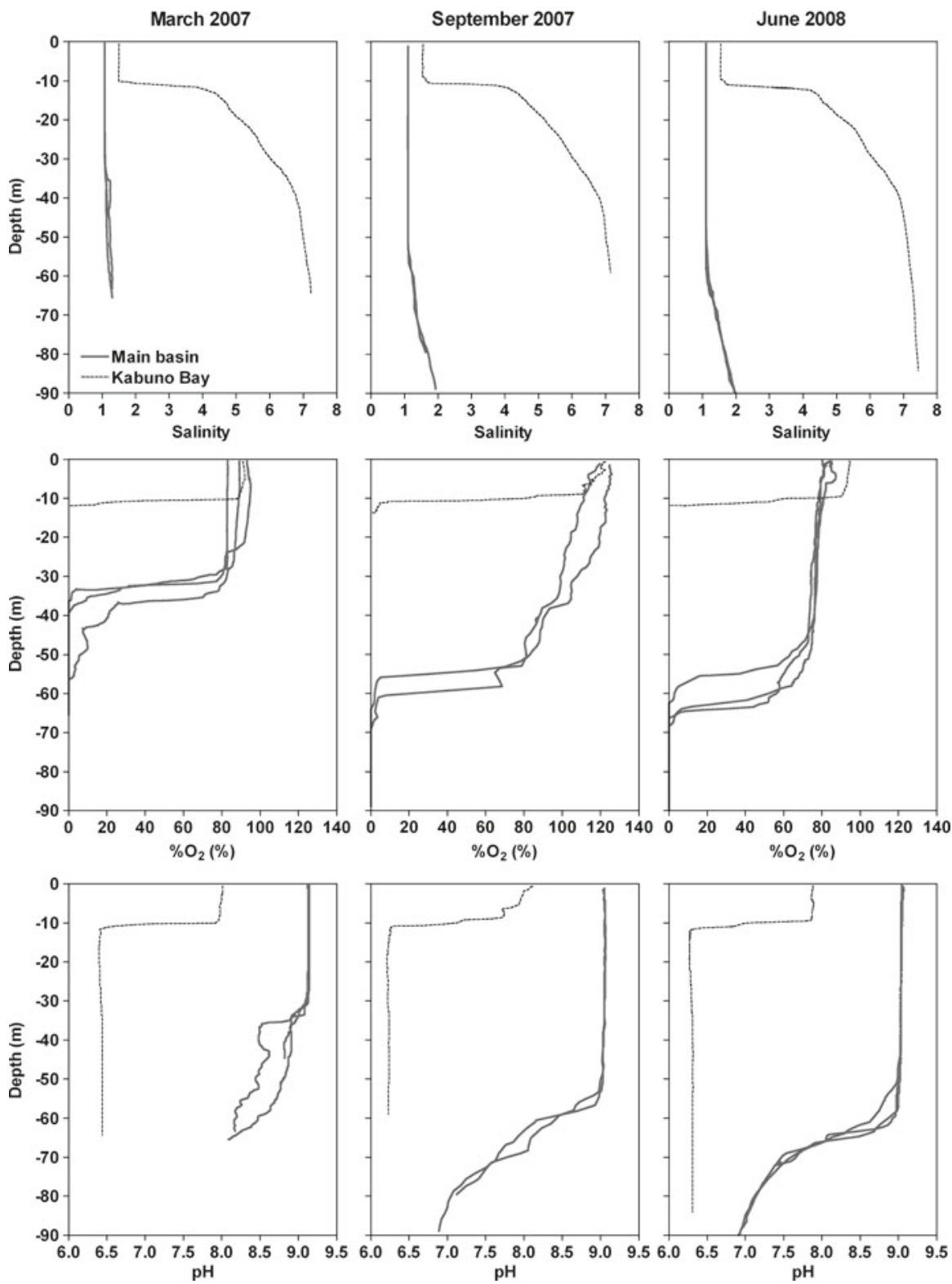

Fig. 4.3 Vertical profiles of salinity, oxygen saturation level $\left(\% \mathrm{O}_{2}, \%\right)$ and $\mathrm{pH}$ in Kabuno Bay and in the three northernmost stations of the main basin of Lake Kivu, in March 2007, September 2007 and June 2008 (vertical profiles were not acquired in April 2009) 

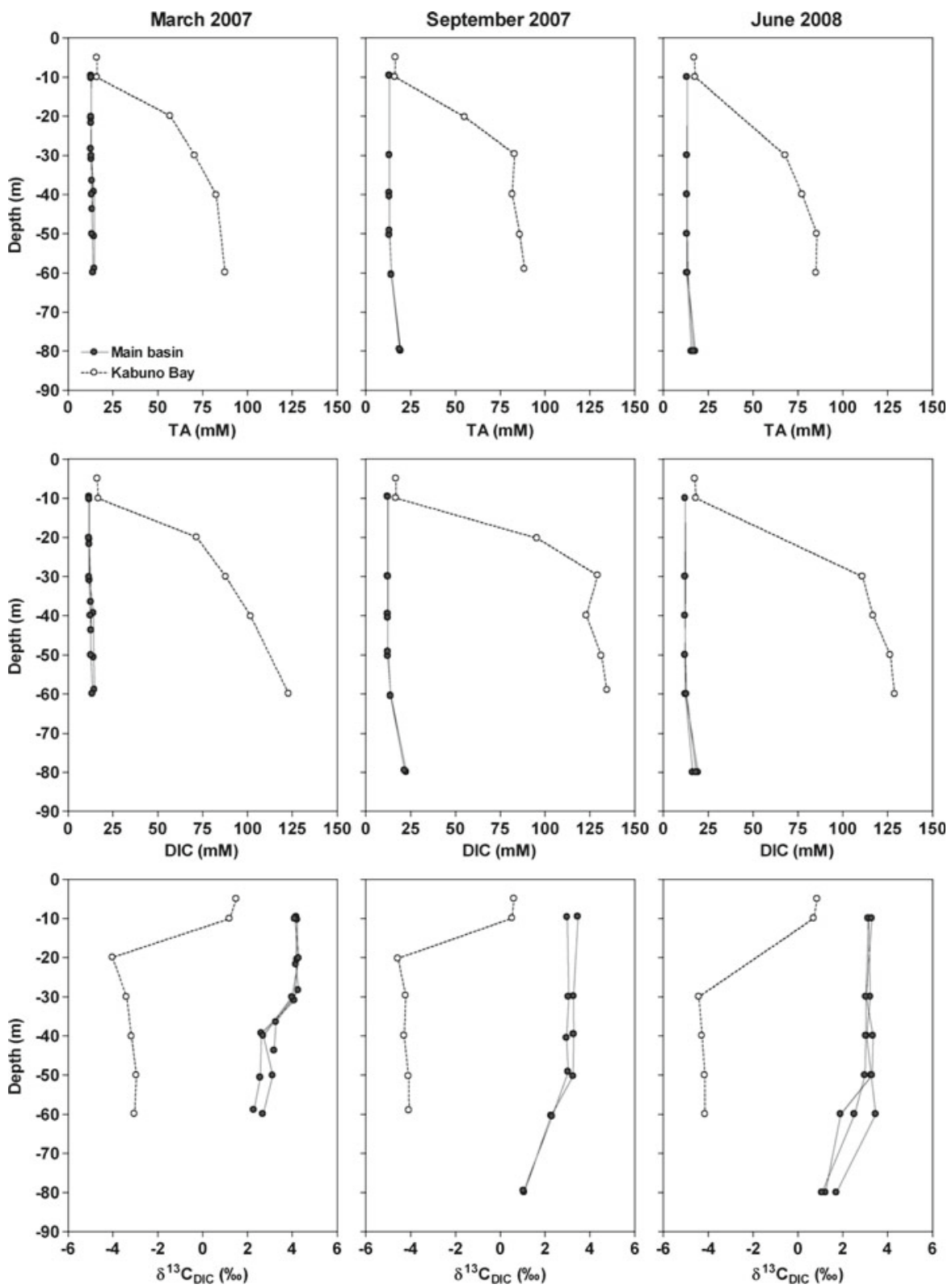

Fig. 4.4 Vertical profiles of total alkalinity (TA, mM), dissolved inorganic carbon (DIC, mM) and $\delta^{13} \mathrm{C}_{\mathrm{DIC}}(\% \circ)$ in Kabuno Bay and in the three northernmost stations of the main basin of Lake Kivu, in March 2007, September 2007 and June 2008 (vertical profiles were not acquired in April 2009) 

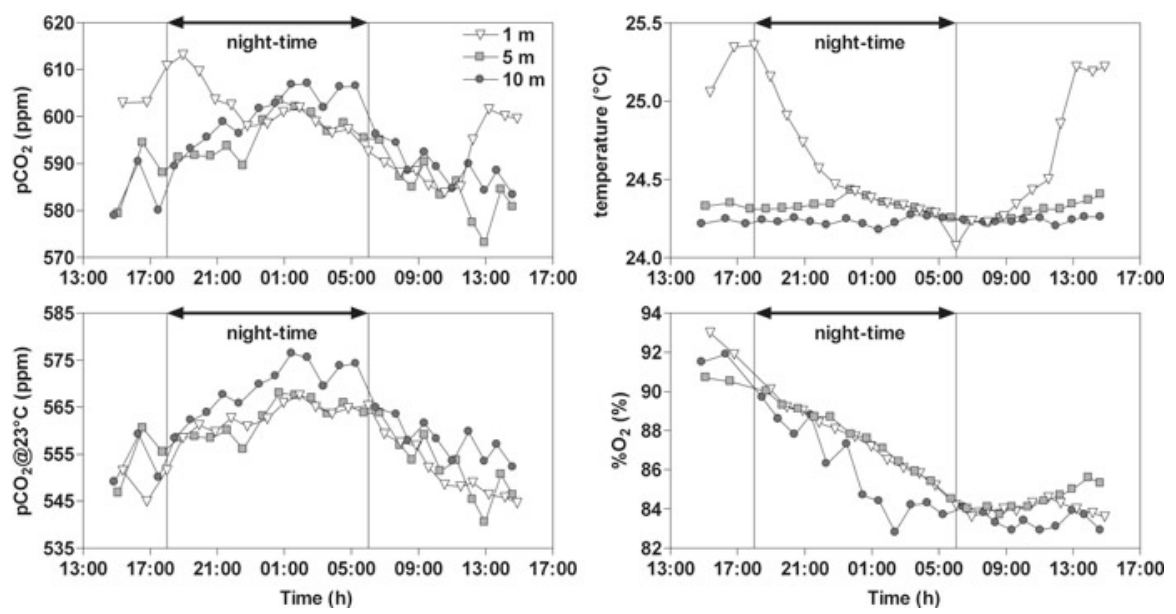

Fig. 4.5 Time series of the partial pressure of $\mathrm{CO}_{2}\left(\mathrm{pCO}_{2}, \mathrm{ppm}\right)$, temperature $\left({ }^{\circ} \mathrm{C}\right), \mathrm{pCO}_{2}$ normalized to a temperature of $23^{\circ} \mathrm{C}\left(\mathrm{pCO}_{2} @ 23^{\circ} \mathrm{C}\right.$, ppm) and oxygen saturation level $\left(\% \mathrm{O}_{2}, \%\right)$ at 1,5 and $10 \mathrm{~m}$ depth at the station indicated by a star in Fig. 4.1 from 23/03/2007 (13:00) to 24/03/2007 $(14: 00)$

$\mathrm{pCO}_{2}$ values were normalized to a temperature of $23^{\circ} \mathrm{C}\left(\mathrm{pCO}_{2} @ 23^{\circ} \mathrm{C}\right)$. At 1,5 and $10 \mathrm{~m}$ depth, $\mathrm{pCO}_{2} @ 23^{\circ} \mathrm{C}$ values increased during night-time and decreased during day-time, as expected from the dominance of community respiration during nighttime and occurrence of primary production during day-time. This was consistent with the $\% \mathrm{O}_{2}$ variations that roughly mirrored those of $\mathrm{pCO}_{2}$. The daily variations of $\mathrm{pCO}_{2} @ 23^{\circ} \mathrm{C}$ at all depths were very consistent, and $\mathrm{pCO}_{2} @ 23^{\circ} \mathrm{C}$ values were lower at $1 \mathrm{~m}$ than at $10 \mathrm{~m}$, as expected from higher biological activity in relation to lower light attenuation in surface waters, and possibly also the loss of $\mathrm{CO}_{2}$ to the atmosphere. Daily variability of $\mathrm{pCO}_{2}$ in March 2007 was similar to the spatial horizontal gradients in surface waters in the main basin of Lake Kivu observed during that cruise.

$\mathrm{CH}_{4}$ concentrations in the surface waters of the main basin were systematically above atmospheric equilibrium $(\sim 2 \mathrm{nM})$, and varied within relatively narrow ranges of 30-75 nM in March 2007, 54-197 nM in September 2007, 30-120 nM in June 2008, and 18-83 nM in April 2009 (Fig. 4.6). In September 2007, $\mathrm{CH}_{4}$ concentrations in Kabuno Bay were within the range of values in the main basin, but they were $\sim 6$ times higher in April 2009, and 8 times higher in both March 2007 and June 2008. $\mathrm{CH}_{4}$ concentrations in surface waters of lakes result from the balance of inputs from depth or laterally from the littoral zone, and of loss terms (bacterial oxidation and evasion to the atmosphere) (Bastviken et al. 2004). Tietze et al. (1980) showed that $\mathrm{CH}_{4}$ concentrations in deep waters of Kabuno Bay are similar to the ones for similar depths in the main basin of Lake Kivu. The likely higher relative contribution of deepwater springs in Kabuno Bay than in the main basin increases the upward flux of solutes and might explain the higher $\mathrm{CH}_{4}$ concentrations observed 

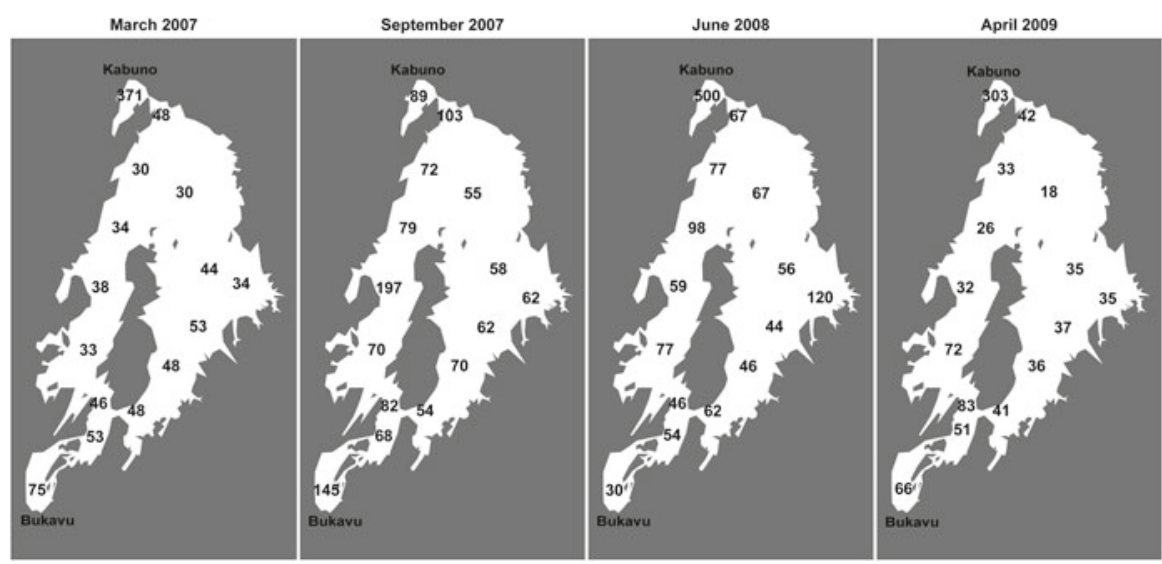

Fig. 4.6 Spatial distribution of the $\mathrm{CH}_{4}$ concentration (nM) in the surface waters of Lake Kivu (10 m depth) in March 2007, September 2007, June 2008 and April 2009 (Borges et al. 2011)

in Kabuno Bay than in the main basin. The shallower oxycline in Kabuno Bay could also promote less removal of $\mathrm{CH}_{4}$ by aerobic bacterial oxidation.

\subsubsection{Seasonal Variations of $\mathrm{CO}_{2}$ and $\mathrm{CH}_{4}$ and Diffusive Air-Water Fluxes}

The average $\mathrm{pCO}_{2}$ in surface waters of each of the four cruises in the main basin of Lake Kivu was positively related to the mixed layer depth and $\mathrm{CH}_{4}$ concentrations, and negatively related to $\delta^{13} \mathrm{C}_{\mathrm{DIC}}$ (Fig. 4.7). This suggests than the deepening of the mixed layer and entrainment of deeper waters to the surface mixed layer is a major driver of seasonal variability of $\mathrm{pCO}_{2}$ and $\mathrm{CH}_{4}$ concentrations in surface waters of the main basin of Lake Kivu. Indeed, deeper waters are richer in $\mathrm{pCO}_{2}$ and DIC (Fig. 4.4; Tietze et al. 1980; Schmid et al. 2005) and $\mathrm{CH}_{4}$ (Tietze et al. 1980; Schmid et al. 2005) than surface waters, and the DIC in deeper waters is more ${ }^{13} \mathrm{C}$-depleted than that in surface waters (Fig. 4.4; Tassi et al. 2009).

Seasonal variations of wind speed were rather modest (coefficient of variation of $13 \%$ ), ranging between $1.2 \pm 0.4 \mathrm{~m} \mathrm{~s}^{-1}$ in September 2007 and $1.6 \pm 0.2 \mathrm{~m} \mathrm{~s}^{-1}$ in June 2008. Hence, seasonal variations of diffusive air-water fluxes of $\mathrm{CH}_{4}$ and $\mathrm{CO}_{2}$ closely tracked those of $\mathrm{CH}_{4}$ concentrations and $\mathrm{pCO}_{2}$. Emissions of $\mathrm{CH}_{4}$ from surface waters in the main basin ranged between $26 \mu \mathrm{mol} \mathrm{m}^{-2} \mathrm{day}^{-1}$ in March 2007 and April 2009 and $50 \mu \mathrm{mol} \mathrm{m}^{-2}$ day $^{-1}$ in September 2007. Emissions of $\mathrm{CH}_{4}$ from surface waters in Kabuno Bay ranged between $53 \mu \mathrm{mol} \mathrm{m} \mathrm{m}^{-2}$ day $^{-1}$ in September 2007 and $185 \mu \mathrm{mol} \mathrm{m}{ }^{-2}$ day $^{-1}$ in April 2009. Emissions of $\mathrm{CO}_{2}$ from surface waters in the main basin ranged between $4 \mathrm{mmol} \mathrm{m}^{-2}$ day $^{-1}$ in March 2007 and $8 \mathrm{mmol} \mathrm{m}^{-2}$ day $^{-1}$ in September 2007. Emissions of $\mathrm{CO}_{2}$ from surface waters 

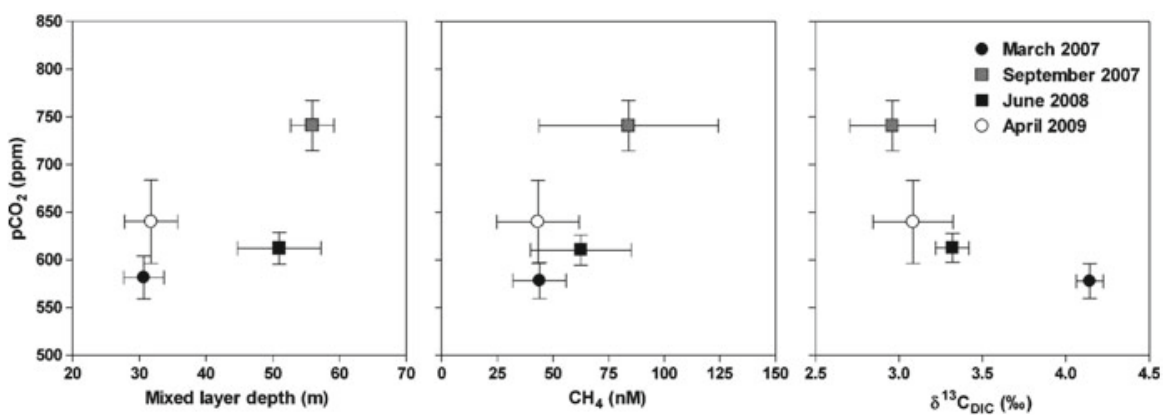

Fig. 4.7 Mean values of the partial pressure of $\mathrm{CO}_{2}\left(\mathrm{pCO}_{2}, \mathrm{ppm}\right)$ in the surface waters $(10 \mathrm{~m})$ versus mixed layer depth $(\mathrm{m})$, versus $\mathrm{CH}_{4}$ concentration in surface waters $(10 \mathrm{~m}, \mathrm{nM})$ and versus $\delta^{13} \mathrm{C}_{\mathrm{DIC}}(\%)$ in surface waters $(10 \mathrm{~m})$ in the main basin of Lake Kivu in March 2007, September 2007, June 2008 and April 2009. Error bars correspond to standard deviations on the mean

in Kabuno Bay ranged between $270 \mathrm{mmol} \mathrm{m}^{-2}$ day $^{-1}$ in September 2007 and $307 \mathrm{mmol} \mathrm{m}^{-2}$ day $^{-1}$ in March 2007.

\subsubsection{Global and Regional Comparison with Other Lakes}

When compared to other lakes globally (Bastviken et al. 2004; Sobek et al. 2005), the main basin of Lake Kivu ranks 3,629th in terms of $\mathrm{pCO}_{2}$ in surface waters (out of 4,904 lakes) and 47th in terms of $\mathrm{CH}_{4}$ concentration in surface waters (out of 49 lakes) (Fig. 4.8). Kabuno Bay ranks 7th in terms of $\mathrm{pCO}_{2}$ and 30th in terms of $\mathrm{CH}_{4}$ concentrations in surface waters.

The comparison of $\mathrm{pCO}_{2}$ and $\mathrm{DOC}$ has been frequently used in limnology for cross-system analysis of $\mathrm{pCO}_{2}$ data (del Giorgio et al. 1999; Riera et al. 1999; Kelly et al. 2001; Sobek et al. 2003, 2005; Roehm et al. 2009; Teodoru et al. 2009). There is in general a positive relationship between $\mathrm{pCO}_{2}$ and $\mathrm{DOC}$ that can be indicative of terrestrial organic matter inputs (as traced by DOC) sustaining net heterotrophy in freshwater ecosystems (as indicated by $\mathrm{pCO}_{2}$ ). Alternatively and not incompatibly, this positive relationship can also be indicative of lateral inputs of both DOC and $\mathrm{CO}_{2}$ from soils by ground-waters and surface run-off. Values in the main basin of Lake Kivu compare surprisingly well to the relationship of $\mathrm{pCO}_{2}$ and DOC established from a global compilation of lakes across all climatic zones (Fig. 4.9), yet at the lower end of values in agreement with the oligotrophic nature of Lake Kivu. Values in Kabuno Bay stand clearly above the relationship of $\mathrm{pCO}_{2}$ and DOC in lakes globally, testifying the role of large contribution of $\mathrm{CO}_{2}$ from subaquatic springs.

$\delta^{13} \mathrm{C}_{\mathrm{DIC}}$ signatures for surface waters in Lake Kivu range between $+2.6 \%$ and $+3.5 \%$ o for the main basin and between $+0.3 \%$ and $+1.5 \%$ o for Kabuno Bay, which is in the higher range of that reported earlier for lakes (Fig. 4.10). $\delta^{13} \mathrm{C}_{\mathrm{DIC}}$ signatures 

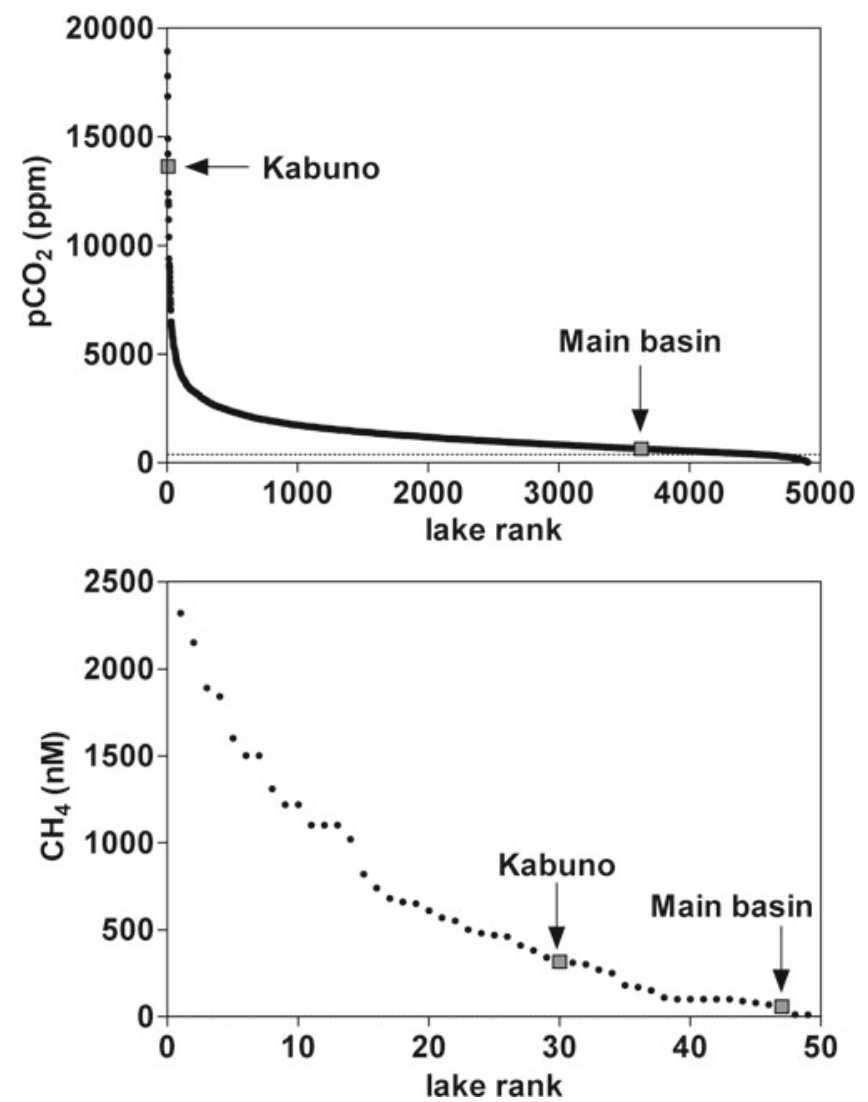

Fig. 4.8 Comparison by rank of the partial pressure of $\mathrm{CO}_{2}\left(\mathrm{pCO}_{2}, \mathrm{ppm}\right)$ and of $\mathrm{CH}_{4}$ concentration $(\mathrm{nM})$ in surface waters of the main basin of Lake Kivu and Kabuno Bay (average of the four cruises at $10 \mathrm{~m}$ ) with global compilations in lakes by Sobek et al. (2005) and Bastviken et al. (2004), respectively

in lakes are to a large extent determined by the geochemistry of the watershed, but are further influenced by biological processes including respiration (which adds ${ }^{13} \mathrm{C}$-depleted $\mathrm{CO}_{2}$ ), photosynthesis (which preferentially removes ${ }^{12} \mathrm{CO}_{2}$, and subsequently leads to higher $\delta^{13} \mathrm{C}_{\mathrm{DIC}}$ ), and methane oxidation (which adds highly ${ }^{13} \mathrm{C}$-depleted $\mathrm{CO}_{2}$ ). In Lake Kivu, the majority of DIC is thought to be of magmatic origin (Schoell et al. 1988), with typically rather ${ }^{13} \mathrm{C}$-enriched signatures between $-7 \%$ and $-4 \%$ o (Tietze et al. 1980). $\delta^{13} \mathrm{C}_{\mathrm{DIC}}$ in surface waters of Lake Kivu are slightly higher and DIC concentrations are consistently higher in Lake Kivu than in Lakes Tanganyika and Malawi (Table 4.1), where the contribution of subaquatic springs is thought to be significantly lower (Table 4.2). Given the very high DIC concentrations in Lake Kivu, the magmatic inputs likely provide the dominant imprint on $\delta^{13} \mathrm{C}_{\mathrm{DIC}}$ signatures, although seasonal and depth variations (Figs. 4.4 and 4.7) clearly hold information on the mixing regime and biological processes which 


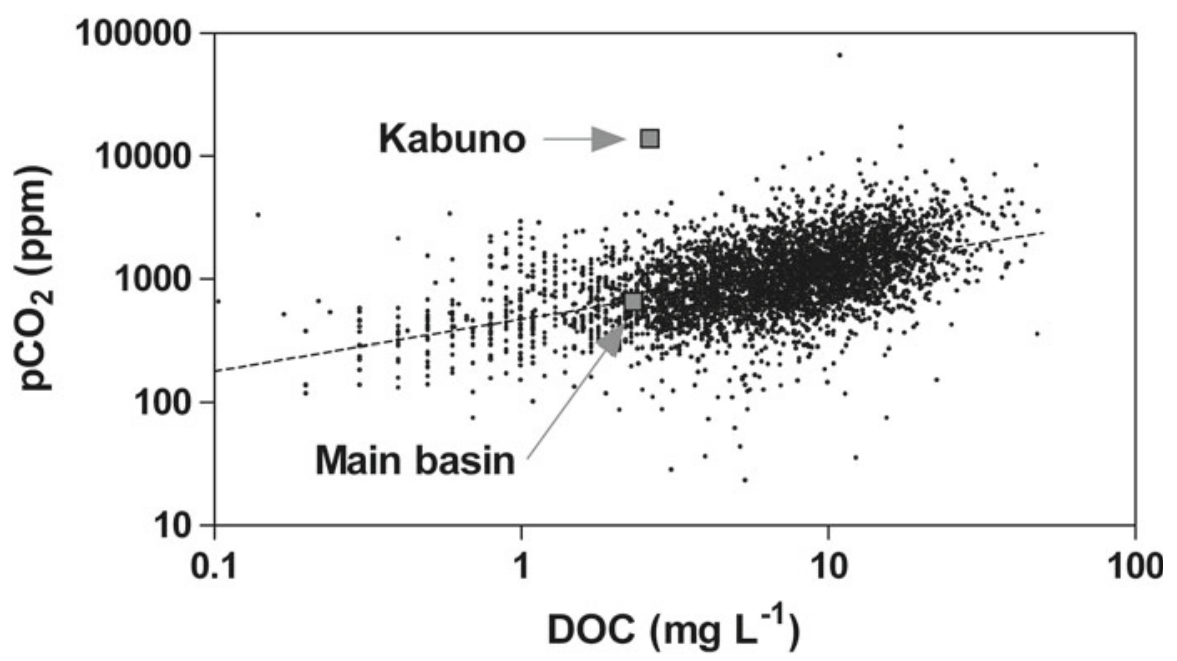

Fig. 4.9 Relationship between partial pressure of $\mathrm{CO}_{2}\left(\mathrm{pCO}_{2}\right.$, $\left.\mathrm{ppm}\right)$ and dissolved organic carbon (DOC, $\left.\mathrm{mg} \mathrm{L}^{-1}\right)$ in lakes reported by Sobek et al. $\left(2005 ; \log \left(\mathrm{pCO}_{2}\right)=2.67+0.414 \log (\mathrm{DOC}) ; \mathrm{r}^{2}=0.26\right.$ ) and values in the main basin of Lake Kivu and Kabuno Bay (average of the four cruises at $10 \mathrm{~m}$ )

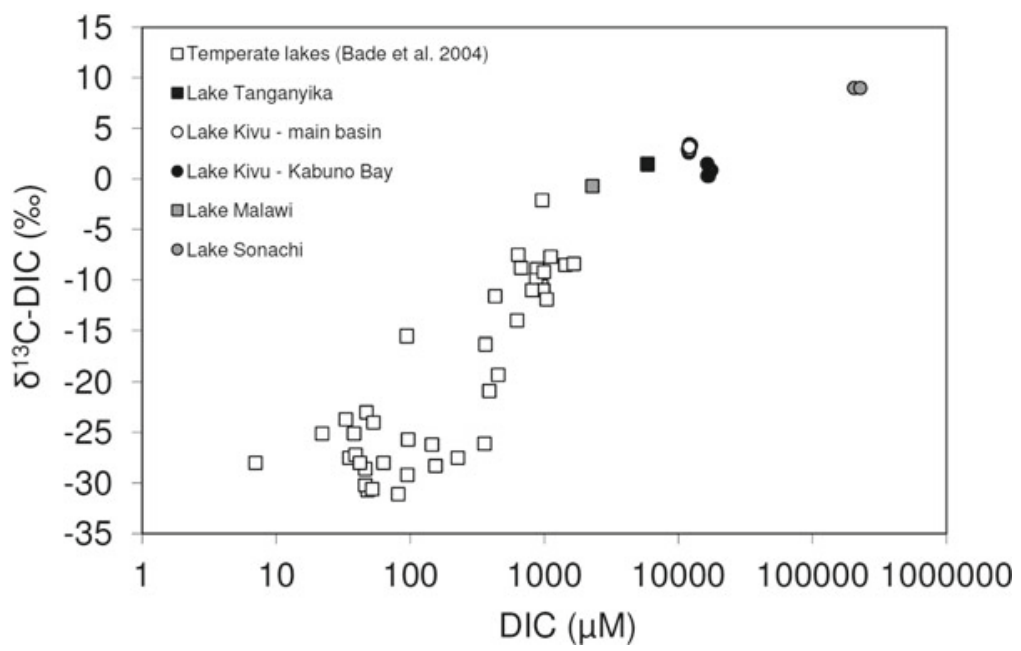

Fig. 4.10 Comparison of dissolved inorganic carbon (DIC, $\mu \mathrm{M})$ concentrations and $\delta^{13} \mathrm{C}_{\mathrm{DIC}}(\%)$ across a range of lakes: Lake Kivu (surface waters from main basin and Kabuno Bay, this study), Lake Tanganyika (Craig 1974), Lake Malawi (Hecky and Hesslein 1995), Lake Sonachi (Kenya, own unpublished data), and from a survey in a range of temperate lakes (Bade et al. 2004)

need to be examined in more detail. Interestingly, data from Lake Sonachi, a small crater lake adjacent to Lake Naivasha, Kenya (see e.g. Verschuren 1999) show even more extreme DIC concentrations $(200-230 \mathrm{mM})$ and $\delta^{13} \mathrm{C}_{\mathrm{DIC}}$ signatures of $+9 \%$ (Fig. 4.10) which is among the highest recorded so far in any lake system. The latter 
Table 4.1 Comparison of salinity, total alkalinity (TA, mM), dissolved inorganic carbon (DIC, $\mathrm{mM}$ ) and the partial pressure of $\mathrm{CO}_{2}\left(\mathrm{pCO}_{2}, \mathrm{ppm}\right)$ from surface waters of Lake Malawi (Hecky and Hesslein 1995; Branchu et al. 2010), Lake Tanganyika (Craig 1974), the main basin of Lake Kivu and Kabuno Bay (this study)

\begin{tabular}{llccc}
\hline & Salinity & TA $(\mathrm{mM})$ & $\mathrm{DIC}(\mathrm{mM})$ & $\mathrm{pCO}_{2}(\mathrm{ppm})$ \\
\hline Lake Malawi & 0.2 & 2.33 & 2.3 & N/A \\
Lake Tanganyika & 0.7 & 6.54 & 5.9 & 280 \\
Main basin of Lake Kivu & 1.2 & 13.00 & 12.0 & 640 \\
Kabuno Bay & 1.6 & 16.90 & 17.3 & 13,640 \\
\hline
\end{tabular}

$\mathrm{pCO}_{2}$ data in Lake Tanganyika were computed from original DIC and TA data reported by Craig (1974) using the carbonic acid dissociation constants of Millero et al. (2006), and adjusted to 2008 by accounting for the increase of atmospheric $\mathrm{CO}_{2}$

Table 4.2 Morphometry and hydrology of Lakes Kivu (Chap. 2), Tanganyika and Malawi (Branchu 2001)

\begin{tabular}{|c|c|c|c|}
\hline & Lake Kivu & Lake Tanganyika & Lake Malawi \\
\hline Surface $\left(\mathrm{km}^{2}\right)$ & 2,370 & 32,600 & 28,800 \\
\hline Volume $\left(\mathrm{km}^{3}\right)$ & 580 & 18,880 & 8,400 \\
\hline Precipitation $\left(\mathrm{km}^{3}\right.$ year $\left.{ }^{-1}\right)$ & 3.3 & 32.6 & 44.1 \\
\hline Evaporation $\left(\mathrm{km}^{3}\right.$ year $\left.^{-1}\right)$ & 3.6 & 55.3 & 59.6 \\
\hline Surface inflows $\left(\mathrm{km}^{3}\right.$ year $\left.^{-1}\right)$ & 2.0 & 29.0 & 28.8 \\
\hline Outflow $\left(\mathrm{km}^{3}\right.$ year $\left.{ }^{-1}\right)$ & 3.0 & 6.3 & 12.1 \\
\hline $\begin{array}{l}\text { Flow from subaquatic springs } \\
\left(\mathrm{km}^{3} \mathrm{year}^{-1}\right)\end{array}$ & 1.3 & $?$ & 1.3 \\
\hline Flushing time (years) ${ }^{\mathrm{a}}$ & 193 & 2,997 & 697 \\
\hline Residence time (years) ${ }^{\mathrm{b}}$ & 88 & 306 & 113 \\
\hline
\end{tabular}

avolume/outflow

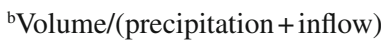

values would be consistent with high primary production and predominantly mantlederived $\mathrm{CO}_{2}$ inputs in this enclosed system.

In Table 4.1, salinity, TA, DIC and $\mathrm{pCO}_{2}$ values from surface waters of Lake Kivu are compared to limited data-sets from Lakes Malawi and Tanganyika. The higher salinity and TA values in Lake Tanganyika than in Lake Malawi are probably related to the higher residence time, flushing time and ratio of evaporation to precipitation in Lake Tanganyika (Table 4.2). The higher salinity, TA, DIC and $\mathrm{pCO}_{2}$ values in Lake Kivu than Lake Tanganyika cannot be explained in terms of higher residence time and flushing time. This would suggest that higher values of these quantities in Lake Kivu are due to subaquatic springs that are undocumented in Lake Tanganyika. Subaquatic springs in Lake Kivu are similar in terms of flow to those in Lake Malawi but the volume of Lake Kivu is more than 14 times smaller, leading to a more intense impact on the chemistry of Lake Kivu. Based on available data, Lake Tanganyika behaves as a sink for atmospheric $\mathrm{CO}_{2}$, while the present data shows that Lake Kivu is a source of $\mathrm{CO}_{2}$ to the atmosphere throughout the annual cycle. The sink of $\mathrm{CO}_{2}$ in Lake Tanganyika should be sustained by an export 


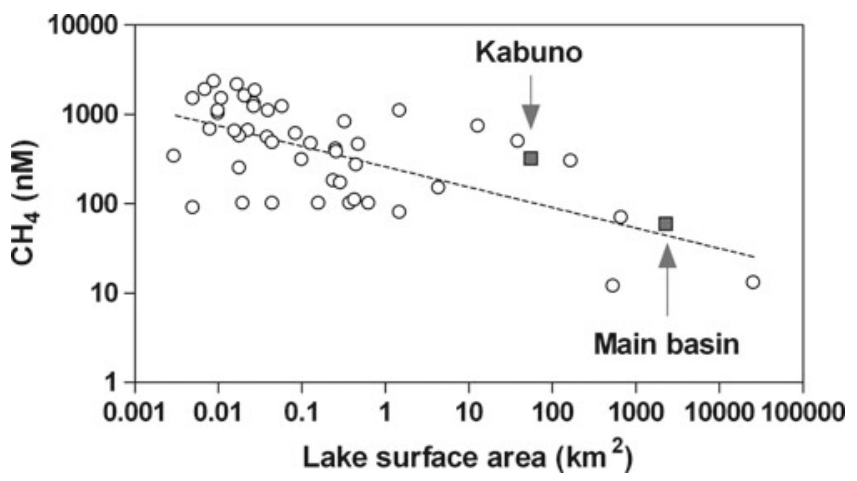

Fig. 4.11 Relationship between $\mathrm{CH}_{4}$ concentration $(\mathrm{nM})$ and lake surface area $\left(\mathrm{km}^{2}\right)$ in the main basin of Lake Kivu and Kabuno Bay (average of the four cruises at $10 \mathrm{~m}$ ) and from the compilation by Bastviken et al. (2004). Relationship between $\mathrm{CH}_{4}$ concentration and lake surface area $\left(\log \left(\mathrm{CH}_{4}\right)=2.42-0.229 \log (\right.$ lake surface area $\left.) ; \mathrm{r}^{2}=0.40 ; \mathrm{p}<0.0001 ; \mathrm{n}=47\right)$ was not originally reported by Bastviken et al. (2004) but is based on the same data-set. Note the higher number of observations of $\mathrm{CH}_{4}$ in lakes smaller than $10 \mathrm{~km}^{2}$ (adapted from Borges et al. 2011)

of organic carbon from surface to depth. There is no reason to believe that Lake Kivu should behave otherwise in the terms of export of organic $\mathrm{C}$ to depth. This would imply that the source of $\mathrm{CO}_{2}$ to atmosphere in Lake Kivu is mainly sustained from inputs to surface waters of DIC from depth (subaquatic springs).

The $\mathrm{CH}_{4}$ concentrations in surface waters of Lake Kivu were surprisingly low compared to lakes globally, considering the huge amounts of $\mathrm{CH}_{4}$ contained in the deep layer of the lake, i.e. concentrations up to $10^{6}$ higher than in surface waters (Schmid et al. 2005). Cross-system comparison of $\mathrm{CH}_{4}$ in surface waters of lakes was carried out as a function of lake surface area (Fig. 4.11). Both Kabuno Bay and the main basin of Lake Kivu fall on the negative relationship between $\mathrm{CH}_{4}$ and lake surface area. There is probably not a unique explanation of the negative relationship between $\mathrm{CH}_{4}$ concentrations and lake surface area, but rather a combination of several factors. In smaller systems there is a higher supply of allochthonous inputs (from catchment and littoral zone) of nutrients and organic $\mathrm{C}$ relative to volume of lake (i.e., large ratio of catchment area to lake surface area). This will sustain high levels of degradation in sediments of organic $\mathrm{C}$ of allochthonous and autochthonous nature (the former sustained by allochthonous nutrient inputs) (Schindler 1971), and promotes a higher flux of $\mathrm{CH}_{4}$ from sediments to the water column in smaller systems. As a first approximation, we can also assume that smaller systems are shallower than larger ones. In shallow systems there will be a higher probability of sediment resuspension coupled to a lower removal of $\mathrm{CH}_{4}$ by bacterial oxidation, due to a shorter distance between sediments and the air-water interface. Finally, in larger systems, there will be a lower fetch limitation of wind induced turbulence and gas transfer velocity (Wanninkhof 1992; Fee et al. 1996) leading to a higher loss of $\mathrm{CH}_{4}$ by 
emission to the atmosphere (for an identical air-water gradient of $\mathrm{CH}_{4}$ ). The lower fetch limitation of wind induced turbulence in larger systems will also promote deeper oxygenated mixed layers, promoting $\mathrm{CH}_{4}$ loss by bacterial aerobic $\mathrm{CH}_{4}$ oxidation.

\subsection{Conclusions}

There are several lines of evidence (see Chaps. 5 and 6) that suggest that the epilimnion of Lake Kivu is net autotrophic, whereby gross primary production exceeds community respiration. This is consistent with the fact that the watershed of Lake Kivu is only about twice as large as the lake surface (Chap. 2), and a very narrow littoral zone due to steep shores, whereby the contribution of allochthonous organic $\mathrm{C}$ inputs to the overall organic $\mathrm{C}$ fluxes in the lake is expected to be minor. We then conclude that the over-saturation of surface waters with respect to atmospheric $\mathrm{CO}_{2}$ and emission of $\mathrm{CO}_{2}$ to the atmosphere (on average for the four cruises: 6 and $289 \mathrm{mmol} \mathrm{m}^{-2}$ day $^{-1}$, in the main basin and Kabuno Bay, respectively) are sustained by inputs of $\mathrm{CO}_{2}$ from depth derived from subaquatic springs and the degradation of organic carbon.

The $\mathrm{CH}_{4}$ concentrations in surface waters of Lake Kivu were surprisingly low compared to lakes globally, considering the huge amounts of $\mathrm{CH}_{4}$ contained in the deep layer of the lake, i.e. concentrations up to $10^{6}$ higher than in surface waters (Schmid et al. 2005). This is related to highly stratified conditions of the lake that promote a very strong removal of $\mathrm{CH}_{4}$ by bacterial oxidation (Jannasch 1975; Pasche et al. 2011) leading to low $\mathrm{CH}_{4}$ concentrations in surface waters, and a modest emission of $\mathrm{CH}_{4}$ to the atmosphere (on average for the four cruises: 36 and $106 \mu \mathrm{mol} \mathrm{m}^{-2} \mathrm{day}^{-1}$, in the main basin and Kabuno Bay, respectively).

Kabuno Bay showed distinct $\mathrm{pCO}_{2}, \mathrm{CH}_{4}, \mathrm{pH}$ and $\delta^{13} \mathrm{C}_{\mathrm{DIC}}$ values compared to the main basin of Lake Kivu, which are related to a larger contribution of subaquatic springs inputs as suggested by vertical profiles of all reported variables. A large contribution of $\mathrm{CO}_{2}$ from subaquatic springs could also explain that Kabuno Bay ranks seventh in terms of $\mathrm{pCO}_{2}$ in surface waters compared to lakes globally, and that values strongly deviate from the relationship between $\mathrm{pCO}_{2}$ and $\mathrm{DOC}$ in lakes globally.

Acknowledgments We are grateful to Boniface Kaningini and Pascal Isumbisho Mwapu (Institut Supérieur Pédagogique, Bukavu, Democratic Republic of the Congo) and Laetitia Nyina-wamwiza (National University of Rwanda, Butare, Rwanda) and their respective teams for logistic support during the cruises, to Sebastian Sobek for sharing his $\mathrm{pCO}_{2}$ database and reviewing the previous versions of the manuscript. This work was funded by the Fonds National de la Recherche Scientifique (FNRS) under the CAKI (Cycle du carbone et des nutriments au Lac Kivu) project (contract $n^{\circ}$ 2.4.598.07), and contributes to the European Research Council starting grant project AFRIVAL (African river basins: catchment-scale carbon fluxes and transformations, 240002) and to the Belgian Federal Science Policy Office EAGLES (East African Great Lake Ecosystem Sensitivity to changes, SD/AR/02A) project. AVB, BD and GL are research associates at the FNRS. FD was a postdoctoral researcher at the FNRS. 


\section{References}

Abril G, Iversen N (2002) Methane dynamics in a shallow, non-tidal, estuary (Randers Fjord, Denmark). Mar Ecol Prog Ser 230:171-181. doi:10.3354/meps230171

Bade DL, Carpenter SR, Cole JJ, Hanson PC, Hesslein RH (2004) Controls of $\delta^{13} \mathrm{C}-\mathrm{DIC}$ in lakes: geochemistry, lake metabolism, and morphometry. Limnol Oceanogr 49:1160-1172. doi:10.4319/lo.2004.49.4.1160

Bastviken D, Cole J, Pace M, Tranvik L (2004) Methane emissions from lakes: dependence of lake characteristics, two regional assessments, and a global estimate. Glob Biogeochem Cycles 18:GB4009. doi:10.1029/2004GB002238

Bastviken D, Tranvik LJ, Downing JA, Crill PM, Enrich-Prast A (2011) Freshwater methane emissions offset the continental carbon sink. Science 331:50. doi:10.1126/science.1196808

Battin TJ, Kaplan LA, Findlay S, Hopkinson CS, Marti E, Packman AI, Newbold JD, Sabater F (2008) Biophysical controls on organic carbon fluxes in fluvial networks. Nat Geosci 1:95-100. doi:10.1038/ngeo101

Borges AV, Abril G, Delille B, Descy J-P, Darchambeau F (2011) Diffusive methane emissions to the atmosphere from Lake Kivu (Eastern Africa). J Geophys Res 116:G03032. doi:10.1029/2011JG001673

Branchu P (2001) Cycle des éléments majeurs et traces dans les grands lacs de rift tropicaux (Lacs Tanganyika et Malawi): processus et enregistrements biogéochimiques. Annales du musée royal de l'Afrique centrale, sciences géologiques, 106, Tervuren, Belgique

Branchu P, Bergonzini L, Ambrosi J-P, Cardinal D, Delalande M, Pons-Branchu E, Benedetti M (2010) Hydrochemistry (major and trace elements) of Lake Malawi (Nyasa), Tanzanian Northern Basin: local versus global considerations. Hydrol Earth Syst Sci Discuss 7:4371-4409. doi:10.5194/hessd-7-4371-2010

Chen Y-H, Prinn RG (2006) Estimation of atmospheric methane emission between 1996-2001 using a 3-D global chemical transport model. J Geophys Res 111:D10307. doi:10.1029/ 2005JD006058

Cole JJ, Caraco NF (1998) Atmospheric exchange of carbon dioxide in a low-wind oligotrophic lake measured by the addition of $\mathrm{SF}_{6}$. Limnol Oceanogr 43:647-656. doi:10.4319/ 10.1998.43.4.0647

Cole JJ, Caraco NF (2001) Carbon in catchments: connecting terrestrial carbon losses with aquatic metabolism. Mar Freshw Res 52:101-110. doi:10.1071/MF00084

Cole JJ, Prairie YT, Caraco NF, McDowell WH, Tranvik LJ, Striegl RG, Duarte CM, Kortelainen P, Downing JA, Middelburg JJ, Melack J (2007) Plumbing the global carbon cycle: integrating inland waters into the terrestrial carbon budget. Ecosystems 10:171-184. doi:10.1007/s10021006-9013-8

Craig H (1974) Lake Tanganyika geochemical and hydrographic study: 1973 expedition. Scripps Institution of Oceanography, University of California, San Diego

del Giorgio PA, Cole JJ, Caraco NF, Peters RH (1999) Linking planktonic biomass and metabolism to net gas fluxes in northern temperate lakes. Ecology 80:1422-1431. doi:10.1890/00129658(1999)080[1422:LPBAMT]2.0.CO;2

Fee EJ, Hecky RE, Kasian SEM, Cruikshank DR (1996) Effects of lake size, water clarity, and climatic variability on mixing depths in Canadian Shield lakes. Limnol Oceanogr 41:912-920

Frankignoulle M, Borges AV (2001) Direct and indirect $\mathrm{pCO}_{2}$ measurements in a wide range of $\mathrm{pCO}_{2}$ and salinity values (the Scheldt estuary). Aquat Geochem 7:267-273. doi:10.1023/A:1015251010481

Frankignoulle M, Borges A, Biondo R (2001) A new design of equilibrator to monitor carbon dioxide in highly dynamic and turbid environments. Water Res 35:1344-1347. doi:10.1016/ S0043-1354(00)00369-9

Gran G (1952) Determination of the equivalence point in potentiometric titrations of seawater with hydrochloric acid. Oceanol Acta 5:209-218 
Hecky RE, Hesslein RH (1995) Contributions of benthic algae to lake food webs as revealed by stable isotope analysis. J N Am Benthol Soc 14:631-653

Jannasch HW (1975) Methane oxidation in Lake Kivu (central Africa). Limnol Oceanogr 20:860-864

Kelly CA, Fee E, Ramlal PS, Rudd JWM, Hesslein RH, Anema C, Schindler EU (2001) Natural variability of carbon dioxide and net epilimnetic production in the surface waters of boreal lakes of different sizes. Limnol Oceanogr 46:1054-1064. doi:10.4319/lo.2001.46.5.1054

Lehner B, Döll P (2004) Development and validation of a global database of lakes, reservoirs and wetlands. J Hydrol 296:1-22. doi:10.1016/j.jhydrol.2004.03.028

Ludwig W, Probst JL, Kempe S (1996) Predicting the oceanic input of organic carbon by continental erosion. Glob Biogeochem Cycles 10:23-41. doi:10.1029/95GB02925

Marotta H, Duarte CM, Sobek S, Enrich-Prast A (2009) Large $\mathrm{CO}_{2}$ disequilibria in tropical lakes. Glob Biogeochem Cycles 23:GB4022. doi:10.1029/2008GB003434

Millero FJ, Graham TB, Huang F, Bustos-Serrano H, Pierrot D (2006) Dissociation constants of carbonic acid in sea water as a function of salinity and temperature. Mar Chem 100:80-94. doi:10.1016/j.marchem.2005.12.001

Miyajima T, Yamada Y, Hanba YT, Yoshii K, Koitabashi T, Wada E (1995) Determining the stable-isotope ratio of total dissolved inorganic carbon in lake water by GC/C/IRMS. Limnol Oceanogr 40:994-1000

Pasche N, Schmid M, Vazquez F, Schubert C, Wüest A, Kessler J, Pack M, Reeburgh WS, Buergmann H (2011) Methane sources and sinks in Lake Kivu. J Geophys Res 116. doi:10.1029 /2011JG001690

Riera JL, Schindler JE, Kratz TK (1999) Seasonal dynamics of carbon dioxide and methane in two clear-water lakes and two bogs lakes in northern Wisconsin, U.S.A. Can J Fish Aquat Sci 56:265-274. doi:10.1139/f98-182

Roehm CL, Prairie YT, del Giorgio PA (2009) The $\mathrm{pCO}_{2}$ dynamics in lakes in the boreal region of northern Québec, Canada. Glob Biogeochem Cycles 23:GB3013. doi:10.1029/2008GB003297

Schindler DW (1971) A hypothesis to explain differences and similarities among lakes in the Experimental Lakes Area, northwestern Ontario. J Fish Res Board Can 28:295-301. doi:10.1139/f71-039

Schmid M, Halbwachs M, Wehrli B, Wüest A (2005) Weak mixing in Lake Kivu: new insights indicate increasing risk of uncontrolled gas eruption. Geochem Geophys Geosyst 6:Q07009. doi:10.1029/2004GC000892

Schoell M, Tietze K, Schoberth SM (1988) Origin of methane in Lake Kivu (East-Central Africa). Chem Geol 71:257-265. doi:10.1016/0009-2541(88)90119-2

Sobek S, Algesten G, Bergström A-K, Jansson M, Tranvik LJ (2003) The catchment and climate regulation of $\mathrm{pCO}_{2}$ in boreal lakes. Glob Chang Biol 9:630-641. doi:10.1046/j.1365-2486. 2003.00619.x

Sobek S, Tranvik LJ, Cole JJ (2005) Temperature independence of carbon dioxide supersaturation in global lakes. Glob Biogeochem Cycles 19:GB2003. doi:10.1029/2004GB002264

Takahashi T, Sutherland SC, Wanninkhof R, Sweeney C, Feely RA, Chipman DW, Hales B, Friederich G, Chavez F, Sabine C, Watson A, Bakker DCE, Schuster U, Metzl N, Yoshikawa-Inoue H, Ishii M, Midorikawa T, Nojiri Y, Körtzinger A, Steinhoff T, Hoppema M, Olafsson J, Arnarson TS, Tilbrook B, Johannessen T, Olsen A, Bellerby R, Wong CS, Delille B, Bates NR, de Baar HJW (2009) Climatological mean and decadal change in surface ocean $\mathrm{pCO}_{2}$, and net sea-air $\mathrm{CO}_{2}$ flux over the global oceans. Deep-Sea Res II 56:554-577. doi:10.1016/j.dsr2.2008.12.009

Tassi F, Vaselli O, Tedesco D, Montegrossi G, Darrah T, Cuoco E, Mapendano MY, Poreda R, Delgado Huertas A (2009) Water and gas chemistry at Lake Kivu (DRC): geochemical evidence of vertical and horizontal heterogeneities in a multibasin structure. Geochem Geophys Geosyst 10:Q02005. doi:10.1029/2008GC002191

Teodoru C, del Giorgio PA, Prairie YT, Camire M (2009) Patterns in $\mathrm{pCO}_{2}$ in boreal streams and rivers of northern Quebec, Canada. Glob Biogeochem Cycles 23:GB2012. doi:10.1029/2008GB003404

Tietze K, Geyh M, Müller H, Schröder L, Stahl W, Wehner H (1980) The genesis of the methane in Lake Kivu (Central Africa). Geol Rundsch 69:452-472. doi:10.1007/BF02104549 
Tranvik LJ, Downing JA, Cotner JB, Loiselle SA, Striegl RG, Ballatore TJ, Dillon P, Finlay K, Fortino K, Knoll LB, Kortelainen PL, Kutser T, Larsen S, Laurion I, Leech DM, McCallister SL, McKnight DM, Melack JM, Overholt E, Porter JA, Prairie Y, Renwick WH, Roland F, Sherman BS, Schindler DW, Sobek S, Tremblay A, Vanni MJ, Verschoor AM, von Wachenfeldt E, Weyhenmeyer GA (2009) Lakes and reservoirs as regulators of carbon cycling and climate. Limnol Oceanogr 54:2298-2314. doi:10.4319/lo.2009.54.6_part_2.2298

Verschuren D (1999) Influence of depth and mixing regime on sedimentation in a small, fluctuating tropical soda lake. Limnol Oceanogr 44:1103-1113. doi:10.4319/lo.1999.44.4.1103

Wanninkhof R (1992) Relationship between wind speed and gas exchange over the ocean. J Geophys Res 97:7373-7382. doi:10.1029/92JC00188

Yamamoto S, Alcauskas JB, Crozier TE (1976) Solubility of methane in distilled water and seawater. J Chem Eng Data 21:78-80. doi:10.1021/je60068a029 